\title{
ANALISIS PERUBAHAN PENGGUNAAN LAHAN TERHADAP KARAKTERISTIK HIDROLOGI DI DAS BULOK
}

\section{(THE ANALYSIS OF THE LAND USE CHANGE TO HYDROLOGIC CHARACTERISTIC OF BULOK WATERSHED)}

\author{
Willy Pratama dan Slamet Budi Yuwono \\ Jurusan Kehutanan Fakultas Pertanian Universitas Lampung \\ Jln. Prof. Dr. Sumatri Brojonegoro No 1 Gedung Meneng Bandar Lampung. 35145 \\ E-mail: pratamaawilly@gmail.com
}

\begin{abstract}
ABSTRAK
Penggunaan lahan merupakan salah satu faktor yang berpengaruh terhadap fungsi tata air suatu daerah aliran sungai (DAS). Kondisi hidrologi DAS Bulok pada saat ini mengalami degradasi. Penelitian ini menganalisis curah hujan, debit sungai, perubahan penggunaan lahan, fluktuasi debit dan koefisien aliran permukaan. Untuk menganalisis perubahan penggunaan lahan terhadap karakteristik hidrologi digunakan metode analisis deskriptif dan tabulasi. Hasil penelitian menunjukkan telah terjadi perubahan penggunaan lahan DAS Bulok meliputi penurunan luas hutan dan pertanian lahan kering bercampur semak, serta peningkatan luas pemukiman dan pertanian lahan kering. Hal tersebut berpengaruh terhadap debit sungai dan koefisien aliran permukaan. Fluktuasi debit DAS Bulok tahun 2001 sebesar 12,45 tahun 2006 menjadi 51,27 dan tahun 2011 menjadi 129,96. Koefisien aliran permukaan DAS Bulok tahun 2001 sebesar 6\% tahun 2006 menjadi 35\% dan tahun 2011 sebesar $41 \%$. Peningkatan fluktuasi debit dan aliran permukaan tahun 2001-2011 menunjukkan DAS Bulok telah mengalami degradasi.
\end{abstract}

Kata kunci: daerah aliran sungai, karakteristik hidrologi, perubahan penggunaan lahan

\section{ABSTRACT}

Land use is one of the factors that have an effect on water system function of a watershed. The characteristic of hidrological condition at Bulok Watershed was degraded. This reaserch was carried out by analyzing data of rainfall, stream discharge, observation land use map, fluctuations of stream discharge and coefficient runoff at 2001, 2006, and 2011. The results of analysis were linked tabulated results with land use in descriptively. The results of this research showed by land use change, which were decreasing forests and mixed dryland farming area, increasing residential area and dryland farming area, which were decreasing forests and mixed dryland farming area, increasing residential area and dryland farming area was caused that the fluctuatoin of stream discharge in 2001 was to 12,45 and increased in 2006 was 51,27 and more increased in 2011 was 129,96. The coefficient runoff of Bulok Watershed has increased in 2001 was to 6\% and increased in 2006 was 35\% and more increased 2011 amounted to 41\%. The increased fluctuation of stream discharge and coefficient runoff 2001-2011 showed that Bulok Watershed was degraded.

Keywords : hydrologic characteristic, land use, watershed 


\section{PENDAHULUAN}

Seiring dengan peningkatan jumlah dan aktivitas manusia, maka kebutuhan terhadap lahan juga mengalami peningkatan. Untuk memenuhi kebutuhan tersebut, manusia cenderung memanfaatkan lahan kearah penggunaan yang lebih tinggi daya gunanya maupun meningkatkan potensi lahannya. Usaha peningkatan daya guna tersebut menyebabkan terjadinya perubahan penggunaan lahan khususnya hutan.

Penggunaan lahan merupakan salah satu faktor yang berpengaruh terhadap fungsi tata air suatu DAS. DAS Bulok merupakan bagian dari DAS Sekampung di Provinsi Lampung. Kondisi hidrologi DAS Bulok pada saat ini mengalami perubahan karakteristik hidrologi DAS yang ditandai dengan meningkatnya potensi banjir karena peningkatan debit sungai pada musim penghujan serta kekeringan pada musim kemarau.

Berdasarkan pada salah satu fungsi lahan sebagai pengatur siklus tersebut, maka pengaruh perubahan penggunaan lahan terhadap karakteristik hidrologi perlu dipelajari. Karakteristik hidrologi yang dijadikan parameter dalam penelitian ini adalah fluktuasi debit dan koefisien aliran permukaan sekaligus menjadi tujuan penelitian ini. Parameter lain yang digunakan adalah data penggunaan lahan di wilayah DAS tersebut pada tahun-tahun pengamatan yang meliputi tahun 2001, 2006, dan 2011.

\section{METODE PENELITIAN}

Penelitian dilaksanakan pada bulan Oktober 2014-Maret 2015 di DAS Bulok yang mencakup wilayah kabupaten Pringsewu dan sekitarnya. Alat yang digunakan dalam penelitian ini adalah Global Positioning System (GPS), kamera, dan perangkat komputer dengan Software pendukung meliputi ArcGIS 10.3 dan Mirosoft Excel. Bahan yang digunakan dalam penelitian ini berupa data curah hujan, data debit air dan peta penggunaan lahan di DAS Bulok tahun 2001, 2006, dan 2011.

Penelitian ini dilakukan dengan beberapa tahapan. Tahap pertama adalah mempersiapkan data. Data yang digunakan dalam penelitian ini adalah data curah hujan bulanan dan debit bulanan pada stasiun SPAS Bulukarto Kabupaten pringsewu, data penggunaan lahan di DAS Bulok, serta kondisi biofisik (topografi). Tahap kedua adalah melakukan cek lapang dan analisis terhadap peta digital. Analisis ini bertujuan untuk mendapatkan data penggunaan lahan di wilayah DAS Bulok dan di setiap stasiun pengamatan yang ada di Bulok. Dalam data penggunaan lahan, jenis penggunaan lahan yang dianalisis dengan cara membandingkan kondisi penggunaan lahan adalah hutan, kebun campuran, lahan kering, semak, pemukiman dan sawah. Tahap ketiga adalah melakukan analisis data terhadap data curah hujan bulanan dan debit bulanan pada tahun 2001, 2006 dan 2011. Analisis ini bertujuan untuk mendapatkan data fluktuasi debit dan koefisien aliran permukaan. Tahap keempat adalah melakukan analisis hubungan terhadap fluktuasi debit dan koefisien aliran permukaan pada tahun 2001, 2006 dan 2011 yang kemudian dihubungkan dengan keadaan perubahan penggunaan lahan di setiap DAS Bulok.

Terdapat dua analisis data yang dilakukan pada penelitian ini. Pertama, Fluktuasi debit yaitu perbandingan debit maksimum (Qmaks) dengan debit minimum (Qmin) pada DAS.

$$
\text { Fluktuasi Debil }=\frac{\text { Qmaks }}{\text { Qmin }}
$$

Sumber: Peraturan Menteri Kehutanan P.61 (2014)

Ket : Qmaks $\left(\mathrm{m}^{3} / \mathrm{det}\right)=$ debit harian rata-rata tahunan tertinggi Qmin $\left(\mathrm{m}^{3} /\right.$ det $)=$ debit harian rata-rata tahunan terendah 
Data Qmaks dan Qmin dperoleh dari nilai rata-rata debit harian dari hasil pengamatan SPAS dan DAS/SubDAS yang dipantau. Nilai fluktuasi debit yang tinggi menunjukkan kisaran nilai Qmaks dan Qmin sangat besar, atau dapat dikatakan bahwa kisaran nilai limpasan pada musim penghujan (air banjir) yang terjadi besar, sedang pada musim kemarau aliran yang terjadi sangat kecil atau menunjukkan kekeringan.

Analisis data yang kedua adalah koefisien aliran permukaan yang merupakan perbandingan antara tebal limpasan tahunan $(\mathrm{mm})$ dengan tebal hujan tahunan $(\mathrm{mm})$ di suatu DAS atau dapat diartikan berapa persen curah hujan yang menjadi aliran permukaan.

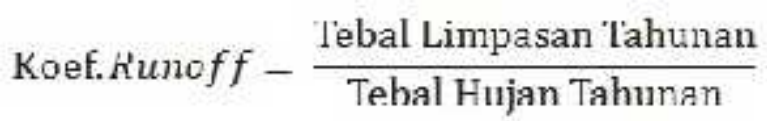

Sumber: Peraturan Menteri Kehutanan P.61 (2014)

Tebal limpasan tahunan diperoleh dari volume debit $\left(\mathrm{m}^{3}\right)$ dari hasil pengamatan Stasiun Pengamat Aliran Sungai di DAS/SubDAS selama satu tahun dibagi dengan luas DAS/SUbDAS (ha atau $\mathrm{m}^{2}$ ) yang kemudian dikonversi ke satuan mm. Sedangkan tebal hujan tahunan diperoleh dari hasil pencatatan pada Stasiun Penakar Hujan baik dengan alat Automatic Rainfall Recorder atau Ombrometer. Koefisien runoff suatu DAS misalnya menunjukkan nilai sebesar 0,4 berarti $40 \%$ dari air hujan yang jatuh di DAS menjadi aliran permukaan (Permenhut P.61, 2014).

\section{HASIL DAN PEMBAHASAN}

\section{Curah Hujan}

Berdasarkan klasifikasi iklim Schmidt-Ferguson dalam Arsyad (2010) diukur dari tahun 2001-2011, curah hujan DAS Bulok memiliki perbandingan rata-rata bulan kering $(<100 \mathrm{~mm} /$ bulan) sebanyak 7 bulan dengan bulan basah $(>100 \mathrm{~mm} /$ bulan) sebanyak 5 bulan, dengan demikian maka DAS Bulok memiliki tipe iklim sedang.

Tabel 1. Curah hujan rata-rata bulanan DAS Bulok tahun 2001-2011.

\begin{tabular}{|c|c|c|c|c|c|c|c|c|c|c|c|}
\hline \multirow{2}{*}{ Bulan } & \multicolumn{11}{|c|}{ Curah hujan (mm) } \\
\hline & 2001 & 2002 & 2003 & 2004 & 2005 & 2006 & 2007 & 2008 & 2009 & 2010 & 2011 \\
\hline Januari & 248,0 & 402,0 & 124,6 & 276,4 & 160,0 & 260,0 & 358,0 & 265,0 & 223,0 & 248,0 & 272,0 \\
\hline Februari & 229,0 & 125,0 & 241,0 & 213,0 & 274,0 & 206,0 & 100,0 & 120,0 & 194,0 & 209,0 & 173,5 \\
\hline Maret & 151,0 & 143,0 & 131,0 & 212,8 & 157,6 & 172,0 & 93,0 & 115,0 & 95,0 & 110,0 & 77,5 \\
\hline April & 148,0 & 112,4 & 57,6 & 139,4 & 448,6 & 143,4 & 144,0 & 90,0 & 151,0 & 154,0 & 164,0 \\
\hline Mei & 179,0 & 112,8 & 150,6 & 149,4 & 82,0 & 137,0 & 86,0 & 98,0 & 82,0 & 85,8 & 71,5 \\
\hline Juni & 51,0 & 6,0 & 91,2 & 20,4 & 117,0 & 49,0 & 56,0 & 125,0 & 33,0 & 51,0 & 59,5 \\
\hline Juli & 115,0 & 136,4 & 11,4 & 40,3 & 74,0 & 49,6 & 34,0 & 49,0 & 22,0 & 34,0 & 23,0 \\
\hline Agustus & 27,0 & 13,2 & 45,2 & 26,6 & 54,0 & 5,7 & 113,4 & 35,0 & 12,0 & 4,0 & 1,5 \\
\hline September & 75,0 & 10,2 & 115,2 & 2,0 & 240,3 & 3,9 & 159,3 & 38,0 & 24,0 & 14,0 & 26,5 \\
\hline Oktober & 76,0 & 2,8 & 122,0 & 26,2 & 91,8 & 6,6 & 90,0 & 112,0 & 91,0 & 60,0 & 67,0 \\
\hline November & 135,0 & 122,0 & 71,0 & 142,4 & 100,6 & 28,2 & 160,0 & 341,0 & 144,0 & 181,0 & 120,0 \\
\hline Desember & 93,0 & 114,4 & 181,7 & 308,0 & 73,0 & 153,8 & 171,0 & 189,0 & 347,0 & 336,0 & 286,0 \\
\hline Total & 1527,0 & 1300,2 & 1342,5 & 1556,9 & 1872,9 & 1215,2 & 1564,7 & 1577,0 & 1418,0 & 1486,8 & 1342,0 \\
\hline Rata-rata & 127,2 & 108,3 & 111,9 & 129,7 & 156,1 & 101,3 & 130,4 & 131,4 & 118,2 & 123,9 & 111,8 \\
\hline Max & 248,0 & 402,0 & 241,0 & 308,0 & 448,6 & 260,0 & 358,0 & 341,0 & 347,0 & 336,0 & 286,0 \\
\hline Min & 27,0 & 2,8 & 11,4 & 2,0 & 54,0 & 3,9 & 34,0 & 35,0 & 12,0 & 4,0 & 1,5 \\
\hline
\end{tabular}

Sumber : Balai Besar Wilayah Sungai Mesuji-Sekampung (2015) 
Kondisi ini menunjukkan potensi air yang berasal dari curah hujan cukup besar. Curah hujan tahun 2001 sebesar $1527 \mathrm{~mm}$ dengan curah hujan tertinggi berada pada bulan Januari sebesar $248 \mathrm{~mm}$ sedangkan hujan terendah terjadi pada bulan Juni sebesar $51 \mathrm{~mm}$ dan memiliki curah hujan rata-rata $127,3 \mathrm{~mm}$ dengan jumlah hari hujan di tahun 2001 sebanyak 90 hari.

Curah hujan tahun 2006 sebesar 1215,2 mm dan curah hujan rata-rata 101,3 mm, dengan curah hujan tertinggi berada pada bulan Januari sebesar $260 \mathrm{~mm}$ dan hujan terendah terjadi pada bulan September sebesar 3,9 mm dengan jumlah hari hujan di tahun 2006 sebanyak 104 hari. Curah hujan total pada tahun 2011 sebesar $1342 \mathrm{~mm}$ dan curah hujan ratarata $111,8 \mathrm{~mm}$, dengan curah hujan tertinggi berada pada bulan Desember sebesar $286 \mathrm{~mm}$ dan hujan terendah terjadi pada bulan Agustus sebesar 1,5 $\mathrm{mm}$ dengan jumlah hari hujan di tahun 2011 sebanyak 109 hari.

Curah hujan total pada 2001 merupakan curah hujan yang cukup besar dengan hari hujan yang sedikit dibandingkan tahun 2006 dan 2011. Intensitas hujan yang besar diwaktu yang singkat dapat menggambarkan nilai curah hujan total besar dengan hari hujan sedikit dalam setahun (Handayani, 2011). Permasalahan ini menjadi salah satu penyebab terjadinya debit air yang cukup besar hingga terjadi koefisien aliran permukaan yang besar.

\section{Penggunaan Lahan}

DAS Bulok memiliki luas 87.670 Ha yang terdiri dari 7 penggunaan lahan yaitu hutan, pemukiman, perkebunan, pertanian lahan kering, pertanian lahan kering campuran, sawah dan semak (tabel 2).

Tabel 2. Perubahan Penggunaan Lahan DAS Betung tahun 2001, 2006, dan 2011.

\begin{tabular}{|c|c|c|c|c|c|c|}
\hline \multirow[b]{2}{*}{ Penggunaan Lahan } & \multicolumn{2}{|c|}{ Tahun 2001} & \multicolumn{2}{|c|}{ Tahun 2006} & \multicolumn{2}{|c|}{ Tahun 2011} \\
\hline & $\begin{array}{l}\text { Luas } \\
(\mathrm{Ha})\end{array}$ & $\%$ & $\begin{array}{l}\text { Luas } \\
(\mathrm{Ha})\end{array}$ & $\%$ & $\begin{array}{l}\text { Luas } \\
\text { (Ha) }\end{array}$ & $\%$ \\
\hline Awan & 3 & 0,05 & 54 & 0,06 & 11 & 0,01 \\
\hline Hutan & 8.670 & 9,89 & 4.301 & 4,91 & 1.376 & 1,57 \\
\hline Pemukiman & 1.765 & 1,97 & 2.552 & 2,91 & 5.994 & 6,84 \\
\hline Perkebunan & 1.896 & 2,16 & 7.460 & 8,51 & 2.322 & 2,65 \\
\hline Pertanian Lahan Kering & 1.137 & 1,29 & 31.850 & 36,33 & 57.431 & 65,50 \\
\hline Pertanian Lahan Kering Campuran & 48.706 & 55,56 & 14.686 & 16,75 & 6.067 & 6,92 \\
\hline Sawah & 23.146 & 26,40 & 23.574 & 26,89 & 9.816 & 11,19 \\
\hline Semak & 2.347 & 2,68 & 3.193 & 3,64 & 4.653 & 5,32 \\
\hline Jumlah & 87.670 & 100,00 & 87.670 & 100,00 & 87.670 & 100,00 \\
\hline
\end{tabular}

Sumber : Balai Pengelolaan Daerah Aliran Sungai Way Seputih-Sekampung (2015)

Penggunaan lahan pada tahun 2001 didominasi oleh pertanian lahan kering campuran dengan luas $48.706 \mathrm{Ha}$ dan persawahan dengan luas 23.146 Ha serta luas hutan yang masih cukup besar $8.670 \mathrm{Ha}$ atau 9,89\% dari luas DAS Bulok. Pertanian lahan kering campuran memiliki luas 55,56\% dari luas total DAS Bulok yang didominasi oleh tanaman kayu dengan fungsi utama penghasil buah dan diantaranya terdapat tanaman penghasil kayu yang masih bercampur semak di selang jarak antar tanamannya.

Perubahan penggunaan lahan pada tahun 2006 terjadi penurunan kuantitas luas pertanian lahan kering campuran yang mendominasi pada tahun 2001 menjadi $14.686 \mathrm{Ha}$ atau $16,75 \%$ dari luas DAS Bulok. Perubahan penggunaan lahan terjadi juga pada areal hutan yang turun 4,98\% dari luas tahun 2001. Perubahan penggunaan lahan ini bergeser pada meningkatnya luas areal penggunaan lahan lainnya seperti pertanian lahan kering, pemukiman, dan perkebunan. Pertanian lahan kering meningkat 35,4\% dari luas DAS tahun 
2001, hal ini terlihat dari keadaan pertanian lahan kering yang paling banyak ditemui adalah kopi (Coffea spp) yang berada pada daerah hulu dan kakao (Therobroma cacao) yang merata pada daerah tengah dan hilir. Perubahan penggunaan lahan pertanian lahan kering bercampur semak ke pertanian lahan kering ditunjukkan dengan berkurangnya semak dan tanaman yang ada pada jarak tanam antar tanaman pokok dalam suatu areal tanam.

Perubahan penggunaan lahan pada 2011 terlihat terjadi peningkatan luas pertanian lahan kering menjadi $65,50 \%$ dari luas DAS Bulok. Bertambahnya penduduk menyebabkan kebutuhan lahan akan tempat tinggal meningkat menjadi 5.994 Ha. Perubahan penggunaan lahan tersebut menyebabkan adanya lahan yang beralih fungsi, ditandai dengan menurunnya luas persawahan, perkebunan dan hutan. Luas hutan di DAS Bulok pada 2011 hanya tersisa $1,57 \%$ dari luas DAS atau $1.376 \mathrm{Ha}$. Penurunan cukup besar lahan persawahan menjadi pertanian lahan kering menunjukkan peran penting pertanian lahan kering dalam kehidupan masyarakat DAS Bulok baik secara ekonomi maupun sosial budaya. Penurunan kuantitas luas sawah juga menunjukkan adanya penurunan debit air sungai untuk menyokong keperluan bercocok tanam dan menggantinya menjadi areal lain yang minim akan keperluan air untuk bercocok tanam dan memenuhi kebutuhan secara ekonomi. Perubahan penggunaan lahan berupa semak mengalami peningkatan menjadi 5,32 \% dari luas DAS. Penggunaan lahan dalam bentuk semak/tanaman penutup tanah apabila ditinjau dari segi konservasi tanah dan air cukup baik, karena dapat mengurangi laju erosi dan aliran permukaan yang dapat meningkatkan resapan air kedalam tanah (Sutrisno, 2011).

\section{Debit Aliran}

Debit aliran menggambarkan respon sistem DAS terhadap input curah hujan secara keseluruhan. Besarnya debit aliran sangat dipengaruhi oleh kondisi tanah, luas tutupan vegetasi, topografi, dan curah hujan yang terjadi (BPDAS, 2008). Pada interval 10 tahun pengamatan terlihat fluktuasi debit menurun cukup besar. Hal ini terlihat pada tahun 2001 sebesar 12,45 yang termasuk dalam kelas sangat rendah dan mengalami kenaikan pada tahun 2006 menjadi 51,27 yang termasuk kelas sedang serta semakin naik di tahun 2011 menjadi 129,96 yang termasuk kelas sangat tinggi (Permenhut P.61, 2014).

Tabel 3. Debit rata-rata bulanan DAS Bulok tahun 2001, 2006, dan 2011.

\begin{tabular}{|c|c|c|c|}
\hline Bulan & $\begin{array}{c}\text { Debit tahun } 2001 \\
\left(\mathrm{~m}^{3} / \text { detik }\right)\end{array}$ & $\begin{array}{c}\text { Debit tahun } 2006 \\
\left(\mathrm{~m}^{3} / \text { detik }\right)\end{array}$ & $\begin{array}{c}\text { Debit tahun } 2011 \\
\left(\mathrm{~m}^{3} / \text { detik }\right)\end{array}$ \\
\hline Januari & 28,70 & 36,45 & 104,91 \\
\hline Februari & 24,64 & 36,95 & 29,27 \\
\hline Maret & 16,28 & 12,40 & 23,39 \\
\hline April & 18,90 & 24,55 & 25,46 \\
\hline Mei & 14,73 & 13,67 & 19,53 \\
\hline Juni & 15,70 & 14,93 & 22,73 \\
\hline Juli & 13,99 & 13,16 & 25,75 \\
\hline Agustus & 13,33 & 11,14 & 15,38 \\
\hline September & 14,48 & 5,10 & 19,72 \\
\hline Oktober & 15,11 & 14,93 & 19,82 \\
\hline November & 15,15 & 17,46 & 23,69 \\
\hline Desember & 16,14 & 12,91 & 40,56 \\
\hline Total & 207,15 & 213,66 & 370,20 \\
\hline Rata-rata & 17,26 & 17,81 & 30,85 \\
\hline Q Maks & 127,00 & 261,25 & 301,54 \\
\hline Q Min & 10,20 & 5,10 & 2,32 \\
\hline Q maks/Q min & 12,45 & 51,27 & 129,96 \\
\hline
\end{tabular}

Sumber: Balai Besar Wilayah Sungai Mesuji-Sekampung (2015) 
Data tersebut menunjukkan bahwa DAS Bulok sudah mengalami degradasi. Asdak (2010) menyatakan apabila fluktuasi debit lebih besar dari 30:1 maka menunjukkan suatu DAS telah mengalami kerusakan. Hal yang sama dinyatakan dalam monitoring dan evaluasi DAS yang diturunkan dari Peraturan Mentri Kehutanan No.P.61/2014 bahwa nilai koefisien rezim aliran (fluktuasi debit) yang tinggi menunjukkan bahwa aliran permukaan pada musim penghujan yang terjadi besar dan pada musim kemarau debit aliran sangat kecil atau menunjukkan kekeringan. Secara tidak langsung kondisi ini menunjukkan bahwa infiltrasi lahan di suatu DAS kurang mampu menahan dan menyimpan air hujan yang jatuh dan air limpasannya banyak yang terus masuk ke sungai dan terbuang kelaut hingga ketersediaan air di DAS tersebut pada musim kemarau sedikit.

Besarnya debit maksimum yang terjadi selain disebabkan oleh curah hujan yang tinggi pada bulan tersebut, juga disebabkan oleh penggunaan lahan. Penurunan nilai fluktuasi debit yang diduga diakibatkan adanya perubahan penggunaan lahan, apabila vegetasi semakin sedikit maka mengakibatkan menurunnya nilai debit maksimum dan debit minimum. Menurut Yuwono (2011) perubahan penggunaan lahan dari areal hutan ke tanaman campuran yang menyebabkan meningkatnya trend fluktuasi debit. Semakin kecil nilai fluktuasi debit, maka semakin baik kondisi tata guna lahan suatu DAS, dan semakin besar nilai fluktuasi debit tersebut, maka semakin buruk keadaan penggunaan lahan di suatu DAS (Arsyad, 2010).

Tabel 4. Perubahan lahan berdasarkan kelerengan DAS Bulok tahun 2001-2011.

\begin{tabular}{|c|c|c|c|c|c|c|c|c|c|c|c|c|c|c|c|c|c|c|c|c|c|}
\hline \multirow{3}{*}{ Lereng } & \multicolumn{21}{|c|}{ Luas penggunaan lahan (Ha) } \\
\hline & \multicolumn{7}{|c|}{2001} & \multicolumn{7}{|c|}{2006} & \multicolumn{7}{|c|}{2011} \\
\hline & Htn & Pm & Prkb & $\mathbf{P k}$ & Pkc & Sw & Smk & Htn & Pm & Prkb & $\mathbf{P k}$ & Pkc & Sw & Smk & Htn & Pm & Prkb & $\mathbf{P k}$ & Pkc & Sw & Smk \\
\hline $0-8 \%$ & 1 & 889 & 0 & 891 & 4742 & 8257 & 223 & 52 & 1089 & 338 & 373 & 1234 & 11563 & 352 & 0 & 2354 & 4 & 8762 & 2730 & 415 & 736 \\
\hline $8-15 \%$ & 392 & 805 & 816 & 241 & 12107 & 12452 & 681 & 619 & 1223 & 4824 & 5091 & 3444 & 10156 & 2138 & 0 & 3180 & 880 & 4316 & 16818 & 496 & 1793 \\
\hline $15-25 \%$ & 3920 & 72 & 1076 & 6 & 26480 & 2414 & 1336 & 1002 & 240 & 2284 & 20991 & 8275 & 1811 & 701 & 97 & 458 & 1437 & 1206 & 30782 & 3 & 1320 \\
\hline $25-45 \%$ & 2049 & 0 & 5 & 0 & 5002 & 23 & 106 & 891 & 0 & 15 & 4830 & 1399 & 44 & 2 & 203 & 1 & 1 & 76 & 6516 & 2 & 387 \\
\hline$>45 \%$ & 2308 & 0 & 0 & 0 & 376 & 0 & 0 & 1736 & 0 & 0 & 565 & 334 & 0 & 0 & 1076 & 0 & 0 & 126 & 1067 & 0 & 416 \\
\hline
\end{tabular}

Keterangan: Htn: Hutan, Pm: Pemukiman, Prkb: Perkebunan, Pk: Pertanian lahan kering,

Pkc: Pertanian lahan kering bercampur semak, Sw: Sawah, Smk: Semak

Tutupan awan tahun 2001=3Ha, tahun 2006=54Ha, tahun $2011=11 \mathrm{Ha}$

Sumber: Data Primer (2015)

Pengunaan lahan yang terjadi pada DAS Bulok yaitu berkurangnya semak dan pertanian bercampur semak dan pada didominasi oleh pertanian lahan kering serta debit sungai yang mengecil dapat dilihat dengan beralihfungsinya sawah menjadi pertanian kering. Selain itu, fluktuasi pada debit maksimum dipengaruhi pula oleh topografinya, dimana $19 \%$ topografinya terdiri dari curam dan agak curam serta $34 \%$ terdiri dari berbukit dan bergelombang. Sehingga walaupun penutupan lahan suatu tempat baik namun karena kemiringannya yang cukup curam mengakibatkan air yang jatuh akan lebih banyak menjadi aliran permukaan (Purba, 2009). Terlebih dengan didominasi oleh tanaman monokultur pada lahan pertanian lahan kering, baiknya dilakukan penerapan tindakan konservasi tanah dan air yang tepat agar lahan tetap lestari (Banuwa, 2008). Kondisi seperti ini menyebabkan terjadinya debit yang tinggi, terutama apabila terjadi hujan dalam intensitas tinggi dan relatif lama. Debit air yang menurun pun terjadi akibat pengelolaan air dengan adanya bendungan/irigasi dengan peruntukan pertanian. 
4. Koefisien aliran permukaan (Runoff Coefficient)

Daerah aliran sungai merupakan suatu ekosistem yang terdiri dari komponen biotik dan abiotik. Aktifitas komponen ekosistem selalu memberi pengaruh terhadap komponen ekosistem yang lain. Aktifitas dalam DAS yang menyebabkan perubahan ekosistem misalnya perubahan tata guna lahan (Asdak, 1995).

Penggunaan lahan merupakan salah satu faktor yang berpengaruh dalam meningkatkan koefisien aliran permukaan. Penggunaan lahan yang cukup baik akan membuat nilai koefisien aliran permukaannya rendah sedangkan penggunaan lahan yang kurang baik akan menyebabkan nilai koefisien aliran permukaannya tinggi.

Tabel 5. Koefisien aliran permukaan DAS Bulok tahun 2001, 2006, dan 2011.

\begin{tabular}{lcccc}
\hline \multirow{2}{*}{ Bulan } & \multicolumn{3}{c}{ Koefisien aliran permukaan $\left(\mathbf{m}^{\mathbf{3}}\right)$} & $\mathbf{2 0 1 1}$ \\
\cline { 2 - 5 } & $\mathbf{2 0 0 1}$ & $\mathbf{2 0 0 6}$ & 0,14 \\
\hline Januari & 0,04 & 0,09 & 0,05 \\
Februari & 0,03 & 0,10 & 0,11 \\
Maret & 0,04 & 0,08 & 0,05 \\
April & 0,04 & 0,09 & 0,10 \\
Mei & 0,03 & 0,04 & 0,13 \\
Juni & 0,11 & 0,14 & 0,40 \\
Juli & 0,04 & 0,12 & 3,51 \\
Agustus & 0,17 & 1,18 & 0,26 \\
September & 0,07 & 1,36 & 0,10 \\
Oktober & 0,07 & 0,71 & 0,07 \\
November & 0,04 & 0,28 & 0,05 \\
Desember & 0,06 & 0,06 & $\mathbf{4 , 9 7}$ \\
\hline Total & $\mathbf{0 , 7 5}$ & $\mathbf{4 , 2 3}$ & $\mathbf{0 , 4 1}$ \\
\hline Rata-rata & $\mathbf{0 , 0 6}$ & $\mathbf{0 , 3 5}$ & \\
\hline
\end{tabular}

Sumber: Data Primer (2015)

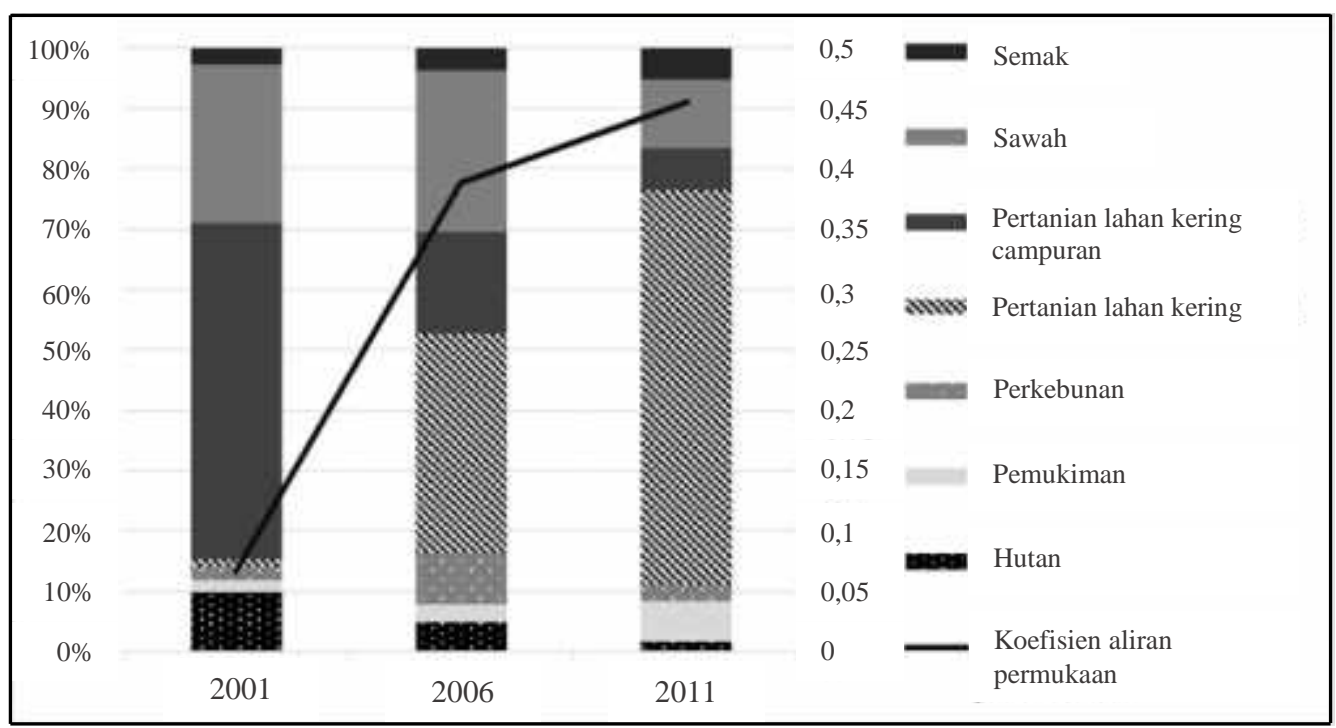

Gambar 1. Perbandingan penggunaan lahan dengan koefisien aliran permukaan DAS Bulok

Parameter karakteristik hidrologi digunakan pada penelitian ini yaitu fluktuasi debit dan koefisien aliran permukaan. Hasil dari penelitian ini menunjukkan secara umum terjadi penurunan kualitas karakteristik hidrologi yang terlihat dengan adanya perubahan penggunaan lahan berpengaruh terhadap koefisien aliran permukaan. Pada tahun 2001 luas hutan dan 
pertanian lahan kering campuran menyebabkan koefisien aliran permukaannya rendah. Sedangkan pada tahun 2011, meningkatnya luas pemukiman dan pertanian lahan kering menyebabkan koefisien aliran permukaan meningkat.

Perubahan penggunaan lahan pada DAS Bulok dengan didominasi perubahan ke areal pertanian lahan kering menimbulkan meningkatnya aliran permukaan (Sutrisno, 2011). Hal ini digambarkan dengan hasil penelitian bahwa pada tahun 2001 DAS Bulok memiliki 6\% limpasan terbawa ke dalam aliran sungai yang masuk dalam kelas sangat rendah. Sedangkan pada 2006 terjadi peningkatan limpasan/runoff sebesar 35\% atau masuk dalam kelas sedang dan makin besar pada 2011 sebanyak 41\% yang termasuk dalam kelas tinggi berdasarkan Peraturan Menteri Kehutanan RI No.P.61/2014. Menurut Asdak (2010), apabila aliran permukaan sudah melebihi 30\% maka mengindikasikan DAS sudah mengalami kerusakan. DAS Bulok mengalami konversi hutan, peningkatan luas pemukiman, peningkatan pertanian lahan kering serta penurunan sawah akibat penurunan debit aliran terutama di musim kemarau.

Dengan luasan hutan yang semakin berkurang digantikan pertanian lahan kering dan pemukiman dalam wilayah DAS Bulok, perubahan kualitas karakteristik hidrologi dapat terjadi. Semakin banyak area terbangun DAS maka proses peresapan air permukaan menjadi air tanah akan terganggu. Hal ini berakibat pada tingginya aliran permukaan serta tingginya debit sungai pada saat musim hujan yang dapat menyebabkan terjadinya banjir. Selain itu berdampak pada minimnya debit sungai pada saat musim kemarau yang berdampak pada menurunnya kualitas air sungai (Suarna, 2008).

Penelitian yang dilakukan oleh Sudadi (1991) menyatakan pengaruh perubahan penggunaan lahan terhadap karakteristik aliran sungai berkaitan dengan berubahnya areal konservasi menjadi pertanian ekstensif menjadi areal pertanian intensif dan pemukiman yang menurunkan kemampuan tanah dalam menahan air. Menurut Asdak (2010), perubahan penutupan lahan yang terjadi dapat meningkatkan debit aliran apabila diantaranya jenis vegetasi diganti dari tanaman berakar dalam menjadi tanaman berakar dangkal. Perubahan penggunaan lahan serta minim tindakan konservasi tanah dan air dapat mempengaruhi volume aliran dan debit puncak (Tola, 2012). Hal tersebut sesuai dengan data yang didapat, perubahan penggunaan lahan menyebabkan air hujan yang mengalir dipermukaan lebih banyak daripada yang meresap kedalam tanah hal tersebut dapat menyebabkan jumlah debit banjir meningkat (Baniva, 2013). Hasil penelitian menunjukkan debit maksimum dalam waktu 10 tahun meningkat dari tahun 2001 sebesar $127 \mathrm{~m}^{3} /$ detik, meningkat pada tahun 2006 sebesar 261,25 $\mathrm{m}^{3}$ detik dan meningkat di tahun 2011 sebesar $301,54 \mathrm{~m}^{3} /$ detik dengan waktu konsentrasi $\left(\mathrm{T}_{\mathrm{c}}\right)$ dengan menggunaan persamaan matematik sebesar 13,30 menit atau setara dengan 0,22 jam (Kirpich, 1940 dalam Asdak, 2010). Hal ini terjadi ketika tanah sepanjang sungai telah jenuh dan semua cekungan bumi lainnya sudah terisi oleh air hujan.

Dari penelitian ini terlihat adanya perubahan penggunaan lahan berpengaruh terhadap naik turunnya fluktuasi debit dan koefisien aliran permukaan (runoff) yang dapat menyebabkan besar kecilnya potensi banjir. Hal tersebut sesuai dengan teori yang dikemukakan oleh Suripin (2002) yaitu komponen hidrologi yang terkena dampak kegiatan pembangunan di dalam DAS meliputi koefisien aliran permukaan, koefisien regim sungai, nisbah debit maksimum-minimum, kadar lumpur atau kandungan sedimen sungai, laju, frekuensi dan periode banjir serta keadaan air tanah. Secara umum perubahan penggunaan lahan akan mengubah karakteristik aliran sungai, total aliran permukaan, kualitas air dan sifat hidrologi yang bersangkutan (Dunne, 1978 dalam Sudadi, 1991). 


\section{KESIMPULAN DAN SARAN}

Kesimpulan

Konversi hutan menjadi areal penggunaan lain seperti berkurangnya lahan hutan dan pertanian lahan kering bercampur semak berganti dengan areal pemukiman dan pertanian lahan kering mempengaruhi karakteristik hidrologi yaitu penurunan debit air khususnya pada musim kemarau dan meningkatnya aliran permukaan pada curah hujan tinggi di DAS Bulok. Hal ini terlihat dari fluktuasi debit pada 2001 sebesar 12,45 yang termasuk dalam kelas sangat rendah dan mengalami kenaikan pada 2006 menjadi 51,27 yang termasuk kelas sedang serta semakin naik di 2011 menjadi 129,96 yang termasuk kelas sangat tinggi. Curah hujan yang tinggi dengan kondisi penutupan lahan yang semakin buruk maka menyebabkan sebagian besar air yang jatuh akan menjadi aliran permukaan. DAS Bulok mengalami peningkatan nilai koefisien aliran permukaan yang dari 2001 sebesar 6\% yang termasuk dalam kelas sangat rendah menjadi 35\% yang tergolong kelas sedang pada 2006 serta lebih tinggi pada 2011 sebesar $41 \%$ yang termasuk dalam kelas tinggi.

Saran

Perlu dilakukan perbaikan tata guna lahan dengan memandang aspek ekologi maupun ekonomi berdasarkan keruangan dan penelitian lanjutan berdasarkan aspek sosial ekonomi dan keadaaan terkini DAS Bulok.

\section{DAFTAR PUSTAKA}

Arsyad S. 2010. Konservasi tanah dan air. Buku. IPB Press. Bogor. 396p.

Asdak, C. 2010. Hidrologi dan pengelolaan daerah aliran sungai. Buku. Gadjah Mada University Press. Yogyakarta. 630p.

Baniva, R, Sobriyah, Susilowati. 2013. Simulasi pengaruh tata guna lahan terhadap debit banjir di DAS Keduang. E-Jurnal Matriks Teknik Sipil. 149(1):102-110.

Banuwa, I.S, N. Sinukaban, S.D. Tarigan, D. Daarusman. 2008. Evaluasi kemampuan lahan DAS Sekampung Hulu. Jurnal Tanah Tropika. 13(2):145-153.

BPDAS, 2008. Karakteristik DAS Way Sekampung. Buku. BPDAS Way Seputih Way Sekampung Press. Lampung. 198p.

Handayani, W, dan Indrajaya, Y. 2011. Analisis hubungan curah hujan dan debit sub DAS Ngatabaru Sulawesi Tengah. Jurnal Penelitian Hutan dan Konseervasi Alam. 8(2): 143-153.

Permenhut P.61, 2014. Peraturan Mentri Kehutanan Republik Indonesia No.P.61/MenhutII/2014. Monitoring dan evaluasi daerah aliran sungai. Kementeri Kehutanan Republik Indonesia. Jakarta. 33p.

Purba, M.P. 2009. Besar aliran permukaan (runoff) pada berbagai tipe kelerengan tegakan Eucalyptus spp. Skripsi. Universitas Sumatra Utara. Sumatra Utara. 78p.

Sutrisno, J, B. Sanim, A. Saefuddin, S.R.P. Sitorus. 2011. Arahan kebijakan pengendalian erosi dan sedimentasi di sub DAS Keduang Kabupaten Wonogiri. Jurnal Ilmiah Ilmu Tanah dan Agroklimatologi. 8(2):105-118.

Suarna, I. W, A. R As-syakur, I. W. S Adnyana, I. W. Rusna, I. A. A. Laksmiati, I. W. Diara. 2008. Studi perubahan penggunaan lahan di DAS Badung. Jurnal Bumi Lestari. 10(2): 200-208.

Sudadi, U.D.P.T. Baskoro, K. Munibah, B. Barus dan Darmawan. 1991. Kajian pengaruh perubahan penggunaan lahan terhadap aliran sungai dan penurunan kualitas lahan di sub DAS Ciliwung Hulu dengan pendekatan model simulasi hidrologi. Laporan Penelitian. Jurusan Tanah. Fakultas Pertanian IPB. Bogor. 85p. 
Suripin. 2002. Pelestarian sumberdaya tanah dan air. Andi Press. Yogyakarta. 326p.

Tola, K.S.K. 2012. Dampak perubahan penggunaan lahan terhadap debit puncak di hulu DAS Jeneberang. Skripsi. Universitas Hasanuddin. Makassar. 65p.

Yuwono, S.B, N. Sinukaban, K. Murtilaksono, B. Sanim. 2011. Land use planning of bulok watershed for sustainable water resources development of Bandar lampung City. Jurnal Tanah tropika. 16(1):77-84. 